\title{
GEOLOGICAL ASPECTS OF COMMONWEALTH ECONOMY
}

$\mathrm{T}$ HE eleventh Inter-University Geological Congress was hold in the Department of Geology, University College, Cardiff, during January 3-5. The subject of the congress was "Geological Aspects of Commonwealth Economy" and more then 120 delegates from at least 20 universities and colleges attended.

The first speaker was J. H. Bean, of the Geological Survey of the Federation of Malaya, who described the iron deposits of Malaya. He pointed out that iron ore has been worked on a commorcial scale in Malaya since 1921, but since the Second World War the industry has heen greatly expanded and now makes a significant contribution to the national economy. About eighteon different iron ore deposits are being worked at the moment, nearly all being located in the proximity of the coast. The iron deposits are found in a wide variety of host rocks-quartzite, schist, quartz porphyry, limestone, andesite, agglomerate, shale, etc.-but one feature common to most of them is that they are associated with granite. The primary iron ore mineral is usually magnetite $\left(\mathrm{Fe}_{3} \mathrm{O}_{4}\right)$, less frequently hæmatite $\left(\mathrm{Fe}_{2} \mathrm{O}_{3}\right)$, and in one deposit it is siderite $\left(\mathrm{FeCO}_{3}\right)$. Mr. Bean described several of the important deposits and then went on to consider the genesis of the iron minerals. He thought the fact that iron ore deposits almost invariably lie close to granite masses indicates a genetic relationship. In several areas magnetite and hæmatite are associated with different phases of mineralization. Thus, in the Kedah Peak area, on the north-west coast of Malaya, magnetite is associated with the pegmatites while the hrematite appears to be of a later hydrothermal origin. In the Ipoh deposit, 100 miles farther south, magnetite is associated with hightemperature silicate minerals, such as garnet and epidote, while the hæmatite is devoid of such minerals, presumably indicating formation at a lower temperature. Probably, the mineralogy of any particular deposit depends on the time of concentration of the mineralizing solutions in relation to the magmatic cycle, with magnetite forming from early solutions and hrmatite from later ones. Finally, Mr. Bean pointed out how the lithology and structure of country rocks control the location and form of ore bodies. Thus, tabular ore bodies are formed in well-bedded shales, but where the rock is of a structureless nature the ore body is irregular. Again, in folded areas ore is usually located along the limbs of folds but rarely along the crests.

The second paper was given by $\mathrm{D}$. Ostle, of the Atomic Energy Division of the Geological Survey of Great Britain. Mr. Ostle discussed prospecting for atomic cnergy minerals. He pointed out that in recent years most attention has been directed at uranium, thorium and beryllium-bearing minerals, and that some work has been done on the geological environments in which helium can be oxpected to occur in economic concentrations, since this element is of potential value in gas-cooled reactors. Mr. Ostle discussed in detail methods of radiometric prospecting, particularly stressing the role of the aeroplane in this respect. Aeroradiometric surveys can $\log$ radioactivity from a height of $500 \mathrm{ft}$. above groundlevel and, properly used, this technique is an invaluable time saver. Where an area is covered by drift normal radiometric survey techniques are useless, and one menns of overcoming this problem is by determining the amount of radon in ground air. Mr. Ostle described other geochemical techniques of prospecting for atomic energy minerals, including systematic sampling and analysis, by fluorimetric and colorimetric means, of uranium in natural ground waters. He also remarked on the selection of geologically favourable areas where these prospecting techniques can be most profitably applied. Thus, it has been found that in igneous rocks, uranium and thorium are largely concentrated in rocks of acidic composition. No deposits of any significance have ever been found in basic igneous rocks.

In the afternoon session, Prof. J. G. C. Anderson, ot University College, Cardiff, dealt with the role of geology in hydro-electric development. He began by saying that although civil engineering excavations have greatly assisted geologists, it was not until comparatively recently that widespread use was made of geological information in the design and structure of major engineering works. Yet the engineering geologist has probably just as important a part to play as the mining and the oil geologist. The use of geology in saving money and ensuring safety in the carrying out of major works can be just as important as in locating mineral and energy resources. In the past 25 years this has become more widely recognized. and in the United States an Association of Engineering Geologists has been founded. Prof. Anderson continued by saying that geological knowledge has three main applications in the construction of major hydro-electric developments. The first is in choosing dam and power station sites where the necessary structure can be built with minimum cost and maximum long-term safety. Where the geology of a dam site is not taken into account the result may be the collapse of the dam. The disaster at Dolgarrog can be cited as an example where only a very superficial examination of the geology of the dam site was made, leading to serious weaknesses in the foundations and abutment. The second application of geology to hydro-electric development is in choosing tunnel routes which afford the optimum geological conditions and avoid structures likely to cause special difficulty and even danger. Prof. Anderson cited many examples, including the Loch Sloy and Rheidol hydroelectric schemes, where a geological investigation had indicated alternative tunnel routes of greater potential efficiency and safety, at no extra cost, other than that, originally planned. He concluded his address by pointing out that the third application of geology to hydro-electric development lies in the location of suitable constructional materials as close to the major works as possible.

In the evening, Dr. P. G. Harris, of the University of Leeds, dealt with recent volcanic eruption on Tristan da Cunha. Dr. Harris, a member of the expedition sent by the Royal Society to the island, outlined the volcanic history of the island, and with the aid of slides traced the ovolution and effects of the recent parasitic volcano. A short film of the volcanic eruption was also shown.

The congress continued the next morning, January 4 , with a paper by Dr. W. Idris Jones, director-general of research at the National Coal Board, on fuel gases in the coal measures. Dr. Jones said that the presence of methane in coal-bearing strata has been a constant, hazard to coal-mining throughout its history. A complete understanding of how methano is stored and emitted by coal and its surrounding strata is still lacking, and research is now being directed to increase fundamental knowledg*? of the coal/methane relationship. In recent years, techniques have been developed that make it possible to drain gas from aeams or worked-out areas, and pipo it to the surface as fuel. Dr. Jones claimed that Britain 
led the world in this technique, and said that possibly, in the near futuro, methane drainage would become part of standard mining practice. He thought the amount of gas which was being wasted nowadays presented a great challenge. Up to 150,000 million cubic feet is lost into the atmosphere every year. Ultimately, coalmines may provide about 10 per cent of Britain's present gas requirements. Dr. Jones also reported on fuel gases which can be derived from coal seams by gasification in situ, the gas produced being led to the surface through boreholes. This involves carbonizing the coal by transmitting heat through it under close control, a technique which has been very successfully used in the U.S.S.R. Dr. Jones concluded by pointing out that both techniques require a knowledge of the geometry and physical properties of the strata in order to exploit natural conditions and obtain maximum yield of gas.

A comparison of oil accumulation conditions in Trinidad and the Canadian Prairies was jointly given by P. Fitzgerald-Moore and Dr. J. Weeda of the Shell International Petroleum Co. Dealing first with the Canadian oil fields, Mr. Fitzgerald-Moore pointed out that oil had accumulated mainly in Upper Palæozoic and Mesozoic sediments. The oil basin lies between a mobile belt and a shield. The general geological history is of geosynclinal warping of the crust, followed by mountain building and foredeep sedimentation, which has migrated shieldwards in time. Oil was found in epicontinental deposits bordering the miogeosyncline, and in quartz sandstones of the early foredeep phase which border, and are derived from, the shield. This latter oil becomes heavier towards the shield and forms an important tar belt. Mr. FitzgeraldMoore stated that other accumulations of oil have been found in transgressive sands of the foredeep, derived from the craton, and regressive sands of the foredeep, from a Cordilleran source. He also described the tectonic structure of the area, in particular, some remarkable flat-lying thrusts in Palæozoic strata. Mr. Fitzgerald-Moore pointed out that the deeper structures of the Cordillera are unknown but he thought there had possibly been a decollement between the crystalline basement and the overlying Palæozoic rocks.

Dr. J. Weeda turned to the Trinidad oil field but first placed it within the framework of the Orinoco Basin. This is essentially Tertiary in age and has followed the same general geological history as the Canadian Basin, although the latter involves far less crustal downwarping. Dr. Weede seid that oil was found in the transgressive and regressive sands in the Orinoco Basin, but in this case the transgressive sands derive from the Cordillera, and the regressive sands from the craton. There was also an extensive tar belt bordering the shield, he added, but only insignificant oil accumulations occurred in the epicontinental deposits. Dr. Weeda concluded by describing the tectonic structure of the Trinidad oil field. This is extremely complex and has been described as "the graveyard of geologists' reputations". The shelf aren is broken by numerous powerful faults and the incompetent Tertiary sediments of the mobile belt exhibit flowage and diapiric structures.

The first lecture in the afternoon session was given by L. C. Noakes, the British Commonwealth Geological Lisison Officer, on underground water in Australia. Threequarters of the Australian continent, said Mr. Noakes, has been described as an 'arid zone'. Although the zone supports only 2 per cent of the population, it provides 40 per cent of Australia's mineral wealth, and 30 per cent and 25 per cent of the beef cattle and sheep population respectively. Underground water supplies have played an extromely important part in the exploitation of mineral resources and the development of pastoral farming. Mr. Noakes commented that the geology of the arid zone divides it into well-marked areas of differing water potential. A quarter of the zone overlies compact, crystalline Pre-Cambrian rocks of low ground-water potential. In this area water accumulates mainly at the interface between weathered and unweathered rock, and in joints and fault zones. A sixth of the zone is underlain by the more permeable Upper Pre-Cambrian rocks, which thus possess a higher ground-water potential. More than half the area overlies major sedimentary basins, such as the great Artesian Basin, which have a high water potential. An appreciable proportion of the underground water in these aroas, Mr. Noakes suggested, may be 'fossil water', derived from pluvial periods hundreds of thousands of years ago, and retained in the rocks ever since. Finally, there are small areas where crystalline Pre-Cambrian rocks are overlain by recent unconsolidated sediments, which act as aquifers. The speaker pointed out that water problems in Australia may be common to a number of States, and this has resulted in the recent founding of the permanent Inter-state Underground Water Conference. Finally, Mr. Noakes emphasized one of the most important and interesting problems in hydrogeology, namely, the establishment of a 'water balance' in artesian water supplies. This ensures, first, that these supplies are not depleted by excessive usage, and secondly, that they are used to their maximum capacity compatible with natural replenishment.

Mr. J. W. Pallister, commissioner of the Geological Survey of Tanganyika, delivered the final lecture of the congress on "The Geological Survey and Economic Development in East Africa". He said that the sosial and economic development of the East African territories can be divided into four phases, and in each the official Geological Surveys have played an important and distinctive part. The first phase broadly occupies the early 1920 's, when the Surveys were established, to the onset of the Second World War. During this period the Surveys were mainly assisting and stimulating the small mining industries which were largely interested in exporting such minerals as gold, tin, mica, copper, lead and diamonds. Mr. Pallister emphasized that the Surveys were busy with many ad hoc investigations, and there was little opportunity for systematic geological mapping. During the Second World War-the second period of economic development-there was a demand for special strategic materials such as wolfram, graphite, kyanite and niobium minerals. Local industries, cut off from normal sources of supply, also developed local raw materials. The third period, which occupies the post-War years up to independence, saw an increased interest in the natural resources of Africa by both the British Government and the local population. During these years the Surveys ombarked on long-term systematic mapping. After some years of prospecting, the partial withdrawal of interest by large outside mining concerns compelled the Surveys to undertake the prospecting and assessing of potential mineral deposits beyond the point when private interests would normally take over. This also coincided with a tendency for the local population to take an increasing part in the prospecting and exploiting of smaller deposits. With independence, Mr. Pallister pointed out, the new countries are eager to develop their natural resources. This development is dependent on outside Governmental or international agencies for funds, and the basic geological information required by these kinds of organizations has stimulated systematic mapping of the geology. Mr. Pallister concluded by saying that the Geological Surveys have always played an important part in developing water supplies. Not only have new water supplies boen developed in areas where oxisting sources are inadequate, but also in areas where sources, although sufficient in quantity, are badly contaminated and soriously affect the health of the local people.

On the last day of the congress, field excursions were arranged to two local coal-mines-the Cwm and Nantgarw Collieries-and also to the Llanharry Iron Ore Mine. Other field trips which were arranged had to be cancelled because of poor weather. 